\title{
LARGE-SCALE RENTAL DEVELOPMENTS AS AN ALTERNATIVE TO HOME OWNERSHIP
}

\author{
Charles F. Lewis*.
}

Tremendous social and economic forces during the past quarter of a century increasingly have centered the attention of the American people upon the necessity of providing better urban housing. The pioneering agitation of the social worker, the rise of the critical viewpoint of the newly emerging science of town planning, the shocking financial experiences both of home owners and of mortgage lenders in the early thirties, the daring socialized experiments of European countries, and the development in America of a few strikingly successful demonstrations of new physical and management patterns have challenged public attention.

All of these various points of interest, however, have been eclipsed by the recent anxiety of government to provide jobs. Today housing is pushed into the forefront of public attention chiefly as a means of providing work and only incidentally as a good end in itself.

One result of the pressures now at work is a certain amount of confusion and conflict. On the one hand the government encourages investment in homes and in large-scale enterprises on a basis of private ownership; on the other hand, it pours out vast sums in subsidies to build government-owned and operated housing. On the one hand the government bailed out owners whose shoe string equities had been wiped away in the depression; on the other hand, it encourages the purchase of homes by families who can make no more than a ten per cent. down payment and guarantees the mortgage written on such a basis.

These, however, are but temporary and transient conflicts. They are the result of the discovery by the politician that the developing housing movement is something he can take over, in part, use, and exploit. In this respect the politician is not essentially different from the old speculative builder and sub-divider. The one was concerned chiefly with making a profit. The other is concerned chiefly with making jobs. Neither has shown any abiding philosophy with respect to the problems of housing. The programs of each have been ruled by expediency. Neither has con-

*A.B., 1909, Allegheny College; LL.D., 1934, University of Pittsburgh. Chief editorial writer, The Pittsburgl/ Stun, I919-1928; Director, The Buhl Foundation, Pittsburgh, since 1928. Aside froin its philanthropic program, the Foundation has invested $\$ 1,700,000$ in the building of Chatham Village in Pittsburgh, a residential community designed to demonstrate the long-term investment sounclncss of large* scale planned housing enterprises managed on a rental basis. 
sistently tried to look at the problem from the point of view of the American family, the ultimate consumer.

Nowhere has the impact of new and swiftly changing social forces been greater than upon the American family. Particularly is this impact reflected in the changing needs and wants of American families with respect to their shelter.

The whole way of life in America for multitudes has altered in the past two generations. Starting slowly, this change swept onward with ever increasing speed until it engulfed our people before they had become even fully conscious of its development.

Among the factors which have changed the face of our life have been: (a) the shift from a village to an urban existence; (b) the shift from handicrafts to mâchine production and from a system of simple proprietorship to one of large enterprise; and (c) the declining size of the American family.

These and other factors, having affected powerfully the way of life and the attitude toward life in America, are changing the wants and needs of American families, inescapably and drastically, with respect to their housing.

The shift from a village to an essentially urban society has brought complexities with which the family alone is no longer able to deal. In the older and smaller units of the social order the common aspiration of every family was to own its own home. To have a bit of the soil, to have a stake in the land was for the average man a proud badge of his independence. He prided himself on his ability to build it, to own it, to protect it. It was to him, in truth, his castle. He looked with ill-concealed superiority upon his less fortunate or less ambitious neighbor who was merely a tenant and who kept his roof over his head only by a landlord's sufferance. The satisfaction in having "elbow room" on acres of one's own, together with the glory of filling one's lungs with the sweet air of freedom, made life worth while.

Almost over night this simple early American family found the village grown up about its house, the village grown into a town, and the town grown into a great city. Bit by bit its land was cut away until finally all that remained of once proud acreage was a narrow city lot with strangers' houses built up close on each side, with noisy commercial and industrial uses just around the corner, and with traffic thundering past the door.

This new existence the family has found precarious. It has been no longer able to police and protect its home. It has delegated police protection, and even the drawing of water, to the city government; and the lighting of its lamps and the cooking of its meals to private enterprise. Against invasions of all sorts in its neighborhood the family is defenseless. It leans more and more on its city government for protection against intolerable social invasions and against destructive industrial incursions.

Under the new order, for great numbers of our people, all of the once vaunted glories of home ownership have passed, the old shibboleths have lost their meaning, and only the hollow fiction remains. 
The shift from a system of handicraft to machine production and from small proprietorship to large enterprise has likewise powerfully affected the family and its attitude toward its house. Under the old order, as under the new, bad times came and went away, but even in bad times for the cobbler there was some work at his bench. But, under the new order, when the factory shuts down there is no work at all. The perils of cyclical employment are greater than ever. To them have been added the perils of technological employment. All have made for economic instability and insecurity.

Associated with these factors has been the mobility of industry itself arising from its great restlessness as it has sought to adjust itself to the pressures of swiftly changing circumstances. This mobility has added to the workers' problem and instability of residence. In the simple, handicraft, rural days a family with confidence could plant itself on the soil for life. Today, large numbers of our people, particularly among the white-collar workers, must as a matter of economic necessity keep themselves free to foliow the beck and call of opportunity or of transfer to a distant city.

It is hardly strange that under the impact of these new forces the American family should be declining in size. It requires for its use, therefore, not so much space either in land or buildings. Convenience and economy more and more have been satisfied by providing that space which is required vertically instead of horizontally. Until recently it has been feared that this process of change might mean that eventually the family would lose contact with the soil altogether. Convenience and economy, mobility and independence, have seemed to be served for these families by renting rather than by owning their homes.

All of these factors are developing a more realistic attitude on the part of multitudes of families toward their housing requirements. It is no longer sufficient to attempt to refute these forces by singing of the "Old Oaken Bucket." The feeling of insecurity brings many families to realize that independence is to be had not by attaching oneself to a city lot but by avoiding long-term commitments which can be terminated only by great difficulty, by great loss, or by both. By sheer force of social and economic necessity American families are forced to substitute practicality for sentimentality in seeking to satisfy their housing needs.

This is not to imply that there is no longer a place for individual home ownership. It has its place. One must have every sympathy with the aspirations of families who want to own their own homes and with every effort of industry and finance to assist them on an honorable basis. But it is time for all of us to recognize that changing conditions of life are making ever increasing numbers of American families to want to rent their homes rather than to buy them.

It must be recognized, too, that until recently there has been no adequate recognition of this great change and little effort to satisfy this tremendous potential market. One reason that in the past so many American families have bought homes, often jerry-built homes, from speculators, has been because there was no decent alternative. Home rental has not been attractive. For the most part landlordism has been ab- 
sentee or amateur. We have lacked in America in any large sense both landlordism based upon constructive investment motives, and property management of a professional nature. Both landlords and property managers have regarded, and too generally still regard, their rented properties as mines to exploit rather than as farms to maintain and improve. Moreover, the homes available for rent even more than the homes available for purchase have been exposed to those social and economic invasions which zoning so far has failed effectively to control or prevent.

In brief, the present situation offers to the American construction industry, the savings institutions, and to business management the opportunity to build a new kind of blight-proof residential community to be managed on a long-term investment basis-a kind of community in which American families can find a way of living suited to their new needs and wants.

The fundamental reason for the hit-or-miss, topsy-turvy development of most American cities is that they have been built small-scale. Capital in the large sense has been busy with building up great enterprises of industry and transportation. In the years of rapid growth and expansion it has neglected the housing field and has left it largely to the speculator and the jerry-builder. Today, the same opportunities for great expansions of industry and transportation no longer exist. On the other hand, a great new market based upon profoundly changing human needs has opened in the field of residential construction. Capital is frankly challenged by this unusual opportunity for soind and productive use of its funds.

Essentially this will be an investment and not a speculative use of capital. And the investment returns to be had now and over a long period of years will compare more than favorably with the experience of industry generally. The results will far surpass those that owners and lending institutions have had with residential real estate under the old and passing systems.

Let us look briefly at the two elements of the proposal: first, that a large part of the new residential building should be in the development of large-scale, planned communities built in one operation from the ground up and managed on a long-term rental basis; and, second, that the object of capital employed in this enterprise should be not quick speculative profit, but sound and secure long-term investment yield.

The practicality of both of these principles has already been convincingly demonstrated in practice. At Chatham Village in Pittsburgh and elsewhere ample evidence is to be found. This experience proves that the large-scale planned community, socially integrated and controlled, held in a single ownership over a period of years and motivated by sound.purposes, will be secure from many of the perils of invasion that beset the ordinary district of single family homes owned by many separate owners. Physical maintenance of all the properties, under large-scale operation, can be permanently guaranteed. The social quality of the community can be guaranteed. The district can be protected from invasions of undesirable use, regardless of the adequacy or the inadequacy of city zoning systems. In short, the districts, if large enough and if wisely administered, can be maintained against neighborhood depre- 
ciation regardless of what may happen in other parts of the city. Such districts can not become obsolete. Such districts will not cease to be taxpaying civic assets.

No less.has it been demonstrated by the so-called limited dividend companies, from Boston in $187 x$ to Pittsburgh and other cities today, that limited dividends pay. Notable is the success of the City and Suburban Homes Company of New York, founded in 1896 by Mr. R. Fulton Cutting and associates. After years of operation, in 1933 in the midst of the depression, this company could boast of assets of nearly $\$ 10,000,000$, a surplus of more than $\$ 1,380,000$, and net earnings of from $\$ 263,000$ to $\$ 445,000$ per year through four depression years. Its average annual dividend rate, from 1899 to 1936 , was $4.65 \%$. Or let us take six non-co-operative apartment projects built in New York City under the New York State Housing Board. All have been consistent dividend payers in good times and in bad. Or let us take, in the City of Washington, the Washington Sanitary Improvement Company, which with assets of nearly $\$ 1,500,000$ can boast that from 1897 to 1923 it paid an annual dividend of five per cent., and from then, straight through the depression, of six per cent. Or the Washington Sanitary Housing Company which has paid five per cent. per annum without interruption since I927. While Chatham Village in Pittsburgh has not yet published earnings statements, those statements when released will give further evidence of the investment soundness of the large-scale housing enterprise on the limited dividend basis.

The only grief of limited dividend companies, apparently, has come from operations too small-scale or from speculative procedures inescapable in installment selling. Where these companies have treated their properties as investments and have continued to operate them on a long-term rental basis, they have been uniformly successful.

The worst handicap of the limited dividend company is its name. Experience abundantly indicates that it might more properly be called an assured dividend company. It serves to point the moral, however, that the business man who goes into the housing field to make a quick speculative profit is very likely to lose his shirt, while if he recognizes the social and economic security of large-scale enterprises, well conceived and well-managed, and seeks an investment return, he may confidently be assured of one of which he will not be ashamed.

The planning, the ownership, and the management of these enterprises invite organization ultimately upon a national scale, and the spread of holdings in many cities will confirm the security and the stability of the investment. Such companies will attract and hold the finest site-planning, architectural, and engineering advice in the country.

The building of such large-scale housing enterprises as have been here discussed not only offers new areas for capital investment, but also opens up inviting fields for completely integrated, nationally operating, home-building companies, capable of applying to large-scale construction sound organization procedures and management policies. Such companies are almost certain to be a development of the comparatively 
early future. In time they will come to control quarries, brickyards, forests, lumber mills, and a wide range of material and equipment factories.

Here, then, is a new industry waiting to be created, an industry capable of employing hundreds of millions of dollars in construction annually, able to stabilize year-round employment for a large part of the building trades, and competent to make a major contribution to economic and social security in the building of cities for the new day, cities composed of residential districts built and kept blight-proof by the application of principles tested and proved in other industries and other investment fields.

Most of the essentials for far-reaching activity in the building of large-scale planned communities on an investment basis are at hand. The market is here, a market probably greater and more eager than any one of us has yet realized. Capital in vast volume is waiting to be put to work. Not in years has five or six per cent. with security seemed to be such a generous yield as it does today.

The chief need today is to implant an understanding of the new idea more widely in the minds of all those who control the availability of mortgage credit. A beginning has already been made in this respect. A framework for financing this new type of housing is provided by the Federal Housing Administration. I Its insurance of mortgages on such projects takes out virtually every element of risk for those who put up the principal funds. Already more than $\$ 50,000,000$ has been underwritten by FHA on large-scale rental projects. Recent changes designed to permit a reasonable attitude toward the profits which may be earned by the equity money should stimulate further action.

The opportunity for American business to get housing under way quickly is at hand. This opportunity arises not only from a serious shortage of housing but also from new needs and new wants which have sprung from new conditions of living in America. There are still many families who will want to own their own homes, but the number of families who do not want to buy and who would flock to planned and managed rental sub-divisions is countless.

${ }^{1}$ For a discussion of the FHA program, see Brabner Smith, The Financing of Large-Scale Rental Housing, infra, p. 608. ED. 